\title{
An Anthropological Study of Naxi's Censer--Building Ritual Taking Sanba Townships as an Example
}

\author{
Yihua Yang $^{1,2}$ \& Yin Zhou ${ }^{1,2}$ \\ ${ }^{1}$ Institute of Chinese Language and Document, Southwest University, Chongqing, 400715, China \\ ${ }^{2}$ Institute of Minority Ethnic Ancient Writing, Southwest University, Chongqing, 400715, China \\ Correspondence: Yihua Yang, Institute of Chinese Language and Document, Southwest University, Chongqing, \\ 400715, China. Tel: 86-23-6825-2385.E-mail: naxiyihua@163.com
}

\author{
Received: March 20, 2015 Accepted: April 27, 2015 Online Published: May 11, 2015 \\ doi:10.5539/ach.v7n2p52 URL: http://dx.doi.org/10.5539/ach.v7n2p52
}

\begin{abstract}
Naxi families with censers in their courtyards burn joss sticks to pray for blessing on the first and fifteenth day every month as well as in festivals. Naxi's joss-burning custom is similar to Tibetan's Weisang ritual, except that the choice of joss sticks is less meticulous and the ritual classics are different. Traditionally, when the Naxi families need to build a censer, they should invite Domba, the priest of Naxi ethnic minority, to divine, build, remove dirty, burn the first joss, and recite the classics. This paper would analyze Naxi's joss sticks burning custom on the base of the censer-building in Dongba village of Sanba Township.
\end{abstract}

Keywords: Naxi, joss-burning, Donba Village, censer-building, ritual

\section{Introduction}

\subsection{The Introduction of Naxi's Joss Burning}

Joss-burning, which can be traced back to Shang dynasty, is a popular folk custom in Chinese daily life, especially in ethnic minority. Naxi's joss-burning custom is similar to Tibetan's Weisang ritual, except that the choice of joss sticks is less meticulous and the ritual classics are different( $\mathrm{Li} \& \mathrm{Xu}, 2007)$.

Naxi ethnic minority mainly lives in Yunnan province, and the majority live in Lijiang, some in Shangri-la. Joss-burning, called " $6 \mathrm{y}^{21} \mathrm{ts}^{55}$ " in Naxi language, is an essential part of daily life in traditional Naxi family every morning. The first thing after getting up is Joss-burning. In order to burn joss, they make fire on fireplace and boil the tea. When the tea is made, the household owner gets the small censer from the Shrine, and pours yesterday's joss ashes into the fireplace. After that, he puts new joss ashes in the censer, adds a shovel of hot embers, puts back the small censer, and offers the first cup of tea to the Naxi God. Meanwhile, the household owner recites the scripture of joss-burning. If he is unable to recite it, he may just pray to the Naxi god.

In Naxi tradition, there is another bigger " $6 \mathrm{y}^{21} \mathrm{ts}^{5} \mathrm{5}^{5}$ "ritual during the first and fifteenth day every month, or on festivals. During these days, Naxi people burn josses not only on the Shrine, but also on the big censer outside, which is formally called "tsho ${ }^{5} \mathrm{pa}^{33} \mathrm{nd} \mathrm{i}^{55}$ ". The whole process would last for 20 minutes. The big censer outside is indispensable in traditional Naxi family, and building the big censer is a religious activity that should invite Naxi's priest--Domba to do the ritual and to participate in building. We are lucky to have the chance to observe a Naxi's censer building ritual during our field investigation in Shangri-la.

\subsection{The Introduction of Investigation Place}

The town of Sanba, located in southeast of Shangri-la, is an autonomous township of Naxi ethnic minority, where Han, Naxi, Yi, Hui, Zang, Lisu live mixedly, and the majority is Naxi. "Ba" in Chinese refers to the plain on the Yunnan-Guizhou Plateau. The name of San Ba originates from the three plains ( or the three "bas" ): Baidi, Dongba, Haba.

Dongba village (N27.6, E100.1) is located in the north of Sanba town government, and the altitude is about $1800 \mathrm{~m}-2900 \mathrm{~m}$. Dongba village is a remote mountainous area, and has built the road to Lijiang and Shangri-la recently. So relatively speaking, Dongba is less subjected to influence from Han culture, therefore Naxi domba culture there is better preserved. 


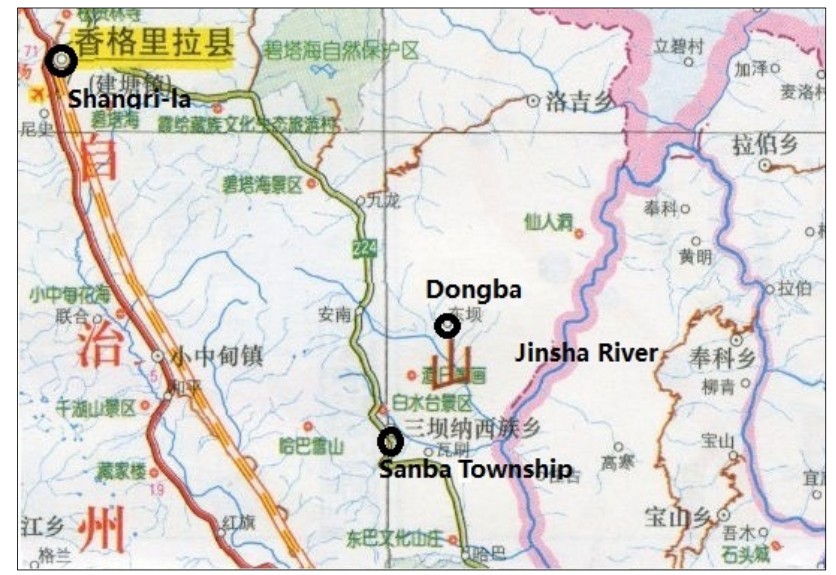

Figure 1. The position of Dongba village (Renmin Traffic Press, 2013:P.28)

\section{The Recording of Censer Building}

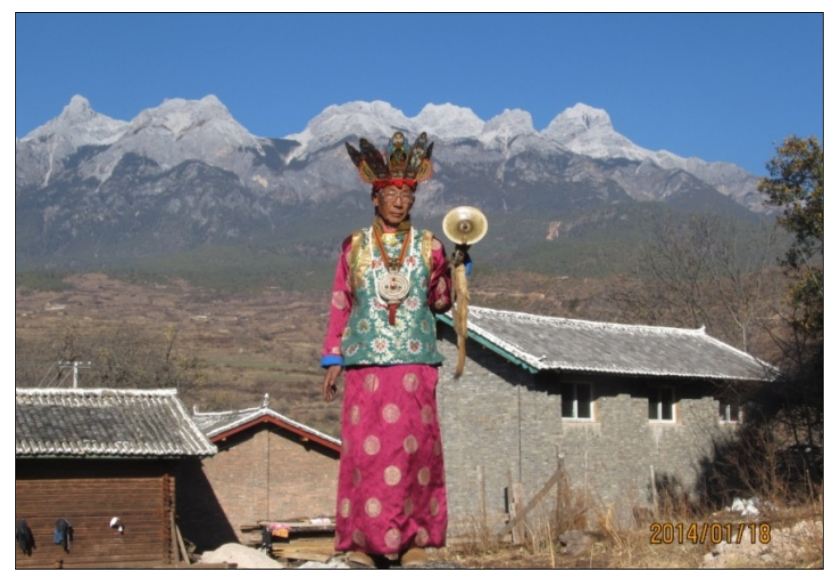

Figure 2. Domba Xi Shanghong

We carry out one-week field investigation in Rishuwan, Dongba village, from Jan $12^{\text {th }}$ to $18^{\text {th }}, 2014$. Our investigation object is Domba Xi-Shanghong in Rishuwan.

We live in Xi's house, and learn Domba scripts and manuscripts from him. So we have many chances to observe the Naxi traditional culture. Every morning, Domba Xi does " $6 \mathrm{y}^{21} \mathrm{ts}_{\mathrm{S}}{ }^{5}{ }^{5}$ " on Shrine, which is a daily activity of worshipping ancestors and the God. During the field study week, many villagers come for divining the reason and solutions of daily troubles, such as toothache, nightmare and study problem, so we have the chance to observe when Domba Xi divines, relieves ghost and prays for the villagers.

On Jan 13th,2014, a sixty-years-old woman, from Gedi, Dongba village, comes to consult Dongba Xi. Her house has moved from the back of the village to the front, and has built a big censer outside near the kitchen. But the family members find the position not good enough, so they invite Domba Xi to divine for an auspicious day and auspicious place to build the big censer. Domba Xi divines and finds that the next day is an auspicious day for building the big censer, and he promises to come next day. In a traditional Naxi area, building big censer requires Domba to hold a ritual and participate in building, so we consult if we can come and observe the building process and the ritual. Then we get permission.

On Jan 14th,2014, we set out for Gedi with Domba Xi. On the way, he introduces Naxi censer culture to us. Every family has a big censer outdoors before 1949, and every 1th, 15th, or festivals, the family host would burn the sticks in the big censer, or go to the "Jiuxian Moutain" to burn Joss and pray for the family. Now, many villagers do not have big censer outside, they only keep the custom of Joss-burning in the house every 1th, 15th, or festivals. Domba Xi tells us that the joss-burning ritual's process and the aim of Tibet and Naxi is almost the same, but the Tibetans' burning more frequently, and the kinds of burning material are more various. The Tibetans burn the joss 
every morning, but most Naxi burn the joss every 1 th, $15^{\text {th }}$ day of the month, or festivals, only few Naxi people keep burning joss every day.

After one hour's itinerary, we finally arrive in Gedi. Before Domba starts the task, the host entertains us with tea and refreshments.

\subsection{Divine the Address}

The host takes us to a location, 10 meters away from the kitchen, where the materials for building the big censer are ready. Before divining to choose the auspicious place, Domba has to do a "ly ${ }^{33}$ " ritual to purify the construction site around. Domba Xi lets the host take out a sieve and 42 white stones. Domba Xi puts the 42 stones in the sieve, lights the burning sticks, waves the lighted sticks upon and down the sieve, and recites the domba scriptures to purify the space and the divine tools. Through this ritual, Domba confirms the space sacramental, so that the divine would be smooth and accurate.

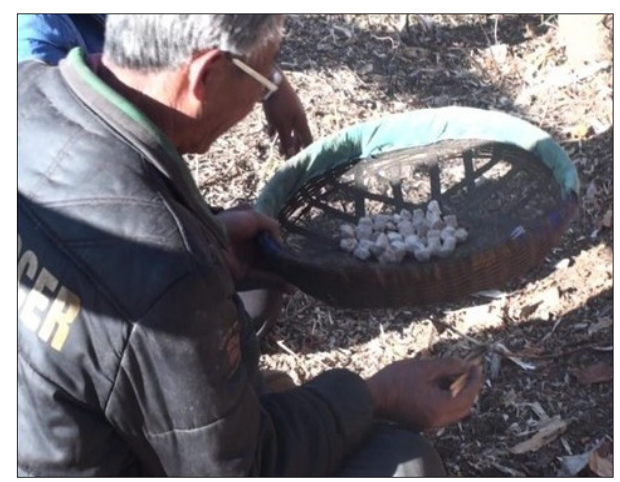

Figure 3. purify the space

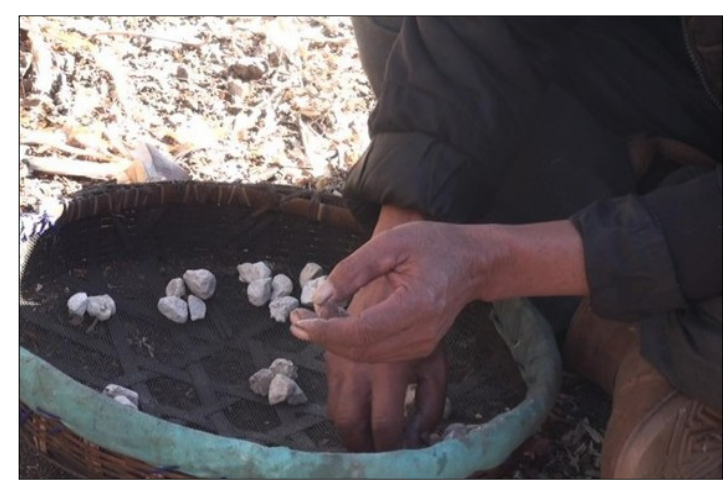

Figure 4. divine the address

After the "ly3" ritual, Domba Xi begins to divine the auspicious place with the 42 white stones, which is called "IV ${ }^{33} \mathrm{ph}^{21}{ }^{21}$. Domba Xi chooses a place, fiddles the stones in the sieve, grabs some and puffs them, repeats the process several times. Then Domba Xi divides the stones into 2 piles, continues to divide one into 3 piles, and the other 4 piles. Observing the 7 piles stones, Domba Xi tells the host this place is not auspicious for building the big censer. Then Domba Xi moves down one metres away, and divines again. This time, Domba Xi divides the stones into 3 piles, and then divides first pile into 2 small piles, the second pile into 4 piles, the third pile into 3 piles. Domba Xi observes the 11 piles of stones for a while, then tells the host this place is auspicious, and delimits the building area.

\subsection{Clean the Place}

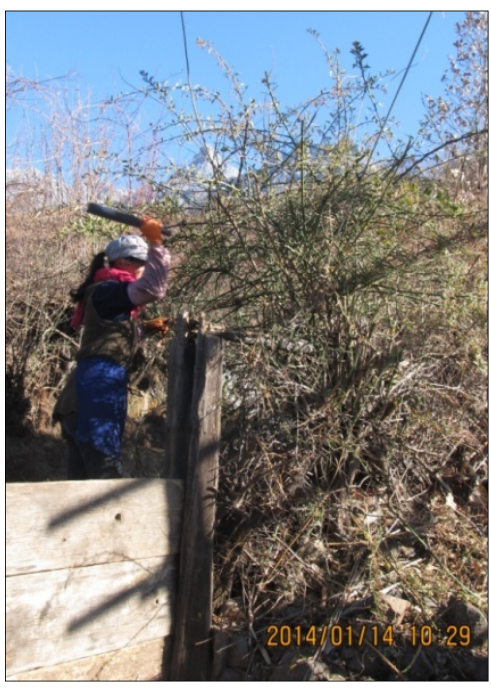

Figure 5. Clean the building place

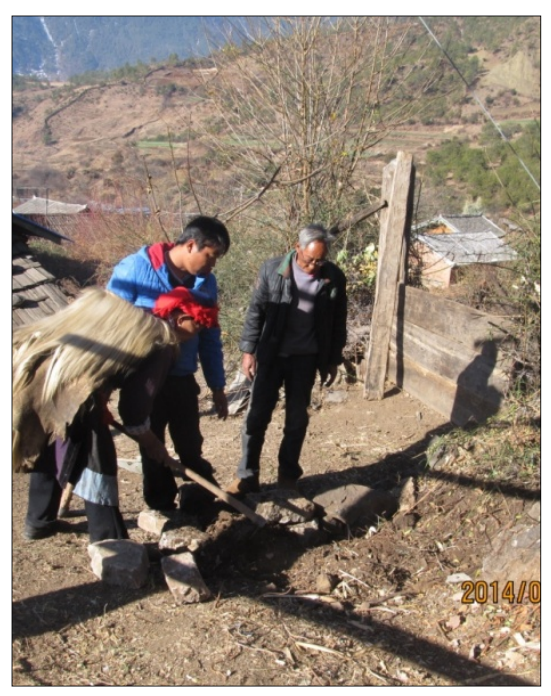

Figure 6 . Clean the building place 
The chosen place is close to the wall, and there are several trees. Domba Xi tells us that it will not be auspicious if the tree grows and covers the censer. In order to build the big censer, and avoid the trees covering the censer, Domba Xi asks the host to cut the trees around and clean up the ground.

The place cleaned is suitable for building the big censer.

\subsection{Build the Censer}

The materials for building the big censer are already prepared, but building the burner needs more white stones, so we help the host to find the suitable stones. Domba Xi begins to build the base of the big censer by laying the stones. When the censer base comes to half a meter high, Domba Xi stops clamping the stones, and starts to pour the cement and sand.

According to Domba Xi's suggestion, the host brings a bowl with rice and tea in it. Domba Xi asks the host if she has silver, which is to be put in the censor building. Domba Xi tells us that putting the silver and gold in the censer can please the Naxi God so that he will bless the family. The son of the host puts his silver necklace and gold ring into the bowl, and gives it to Domba Xi. Domba Xi digs a hole in the middle of the base, puts the bowl into it, and finds a flat brick to cover the bowl. After that,we pour the cement and sand into the base again, thus the base of the burner is basically finished.

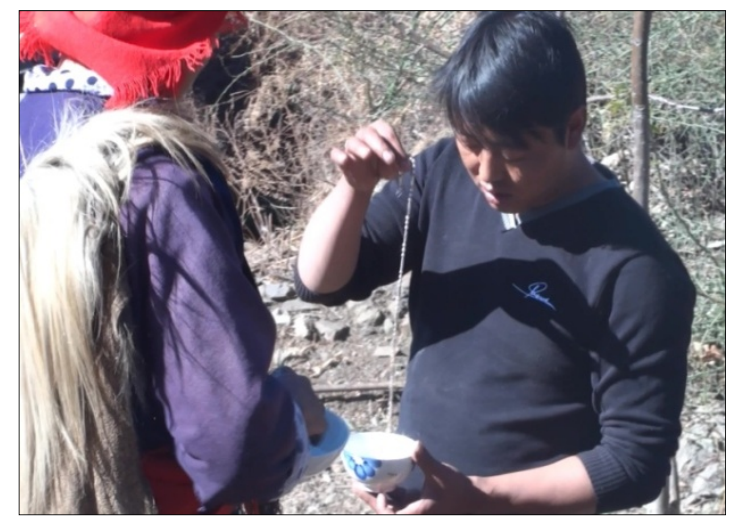

Figure 7. Laying the ring and necklace

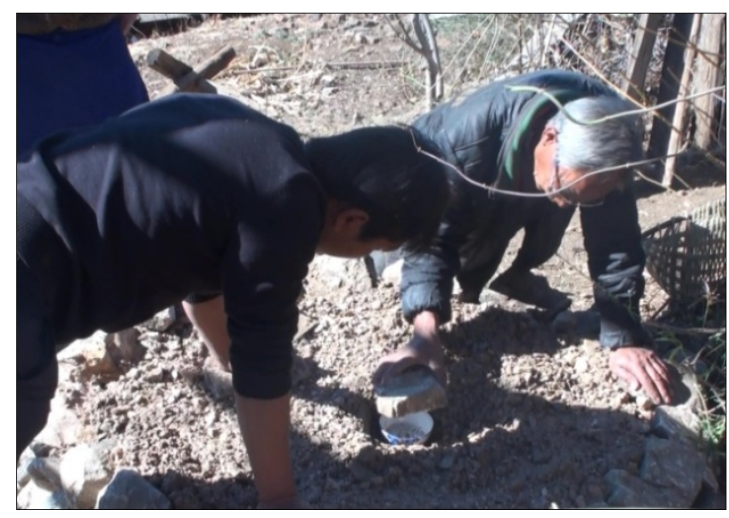

Figure 9. Covering the bowl

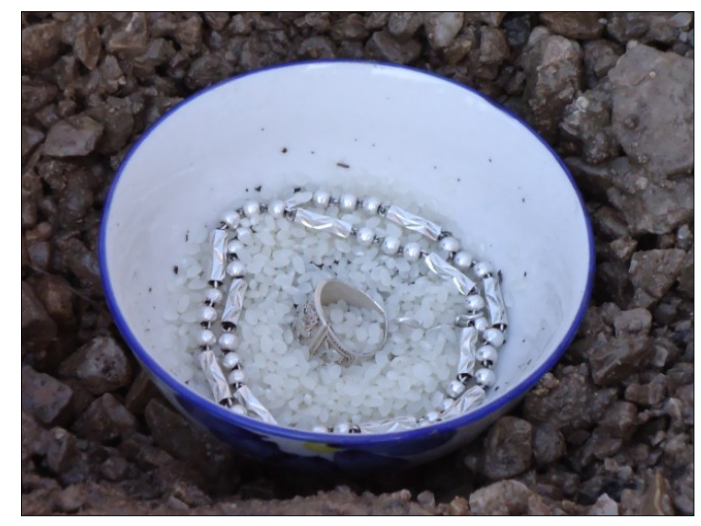

Figure8. The bowl of rice, tea, ring and necklace

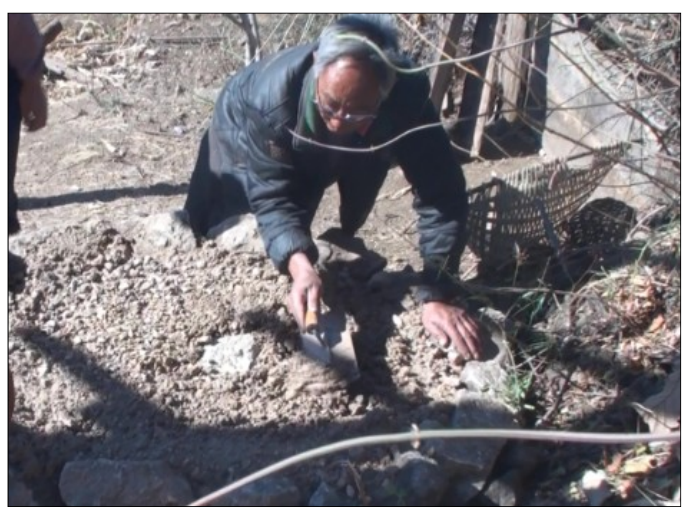

Figure 10. Fixing the base

Then comes the step of building the burner on the base. Domba Xi first uses several big stones to fix the shape of the censer and the position of the censer opening, which is not very smooth. Then we help pour the cement and sand to back up the big censer, leaving a hole on the top. After that, Domba Xi asks the host to bring the chimney pipe, but the chimney pipe is too long. The host cut short the pipe, then puts the pipe on the burner through the hole on the top. But the hole is bigger than the pipe, so we use the small stone to fix it, and pour into the cement and the sand to back up the chimney pipe.

The last step is to set a tower, which is replaced by a tower-shape cypress wood, at the back of the censor. Because the time is limited, the cypress wood hasn't been carved into tower-shape. Domba Xi asks the son of the host to 
sharpen the top side of the wood, and set it at the back of the burner. Domba Xi asks the son of the host to paint the burner to make it smooth and white, and the wood should be carved into tower-shape.

Thus the whole building process is completely finished, lasting for 4 hours in total.

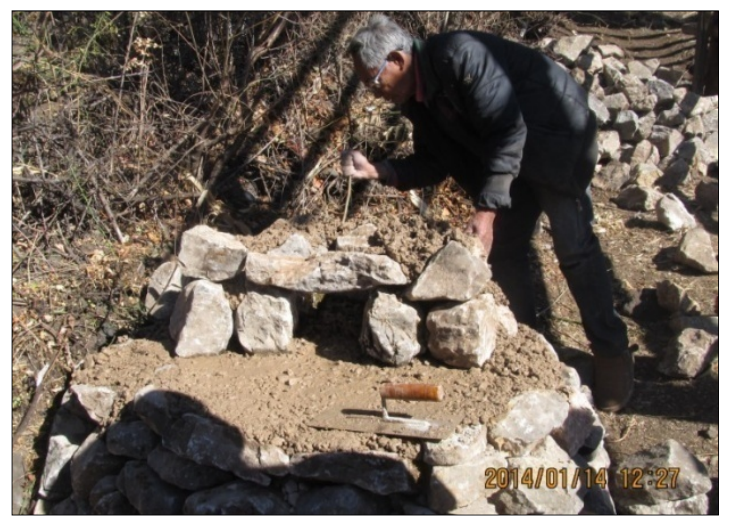

Figure 11. Build the burner

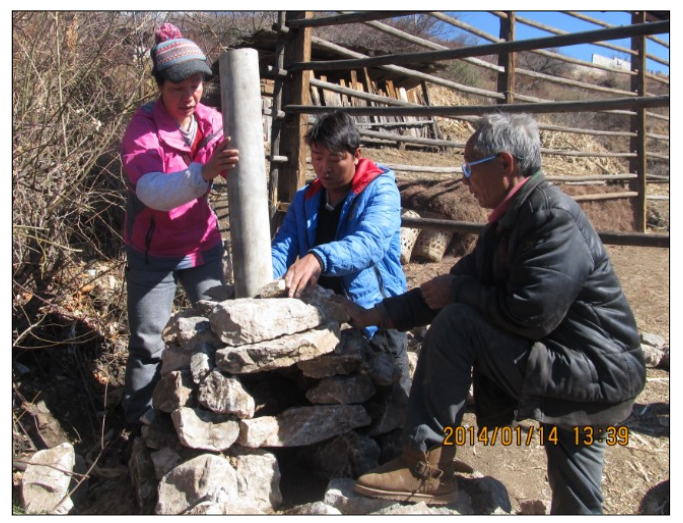

Figure 12. Set the chimney pipe

\subsection{The Ritual of "tsho ${ }^{55} \mathrm{pa}^{33}$ ndti i5s"}

After the building, Domba Xi carries out a ritual of " $\mathrm{tsho} \mathrm{O}^{55} \mathrm{pa}^{33} \mathrm{ndzi}{ }^{55}$ ", then the censer is completely finished in the religious meaning.

Domba Xi asks the host to bring the burner sticks ( the branches of pine and cypress ), a dish of flour, a cup of tea and a bottle of white spirit. He puts together the branches of pine, cypress and rhododendron, which is the burner sticks of Naxi, then adds some torch in them, puts them into the censer, and pours the flour and butter, then lights them, meanwhile, Domba Xi recites the scriptures. Then Domba Xi adds the torch to branches of rhododendron, ignites them, moves around the burner up and down, and recites the scriptures of "ly ${ }^{33}$ " to purify the newly built censer. After that, Domba Xi pours the tea and white spirit to the tower, recites the scriptures of "tsho ${ }^{55} \mathrm{pa}^{33} \mathrm{n}$ ctzi ${ }^{55}$ ". In the end, Domba Xi asks the whole family to worship on bended knees. The whole reciting lasts for 20 minutes

After all these procedures, the whole censer building work comes to an end.

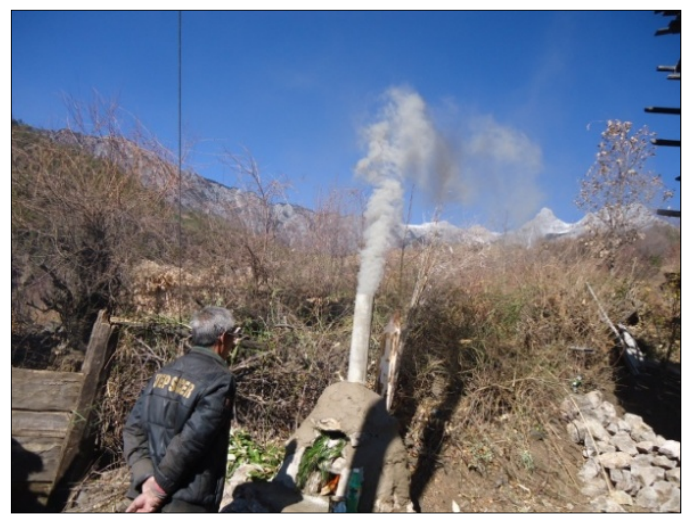

Figure 13. Domba $\mathrm{Xi}$ is reciting the scriptures

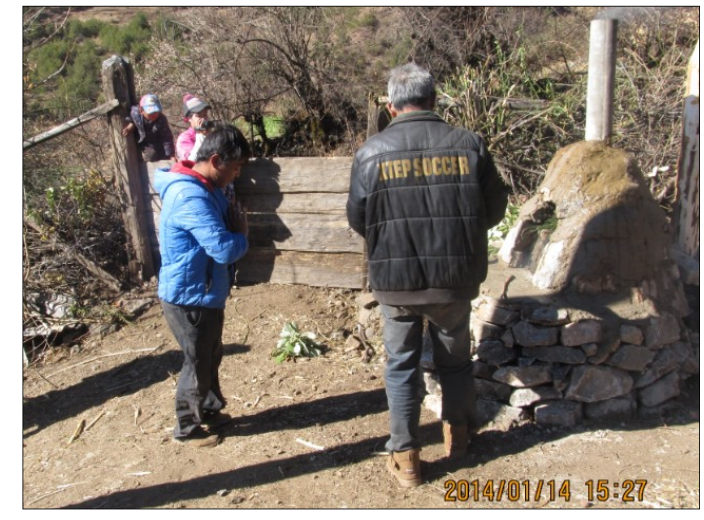

Figure 14. The host is worshiping 

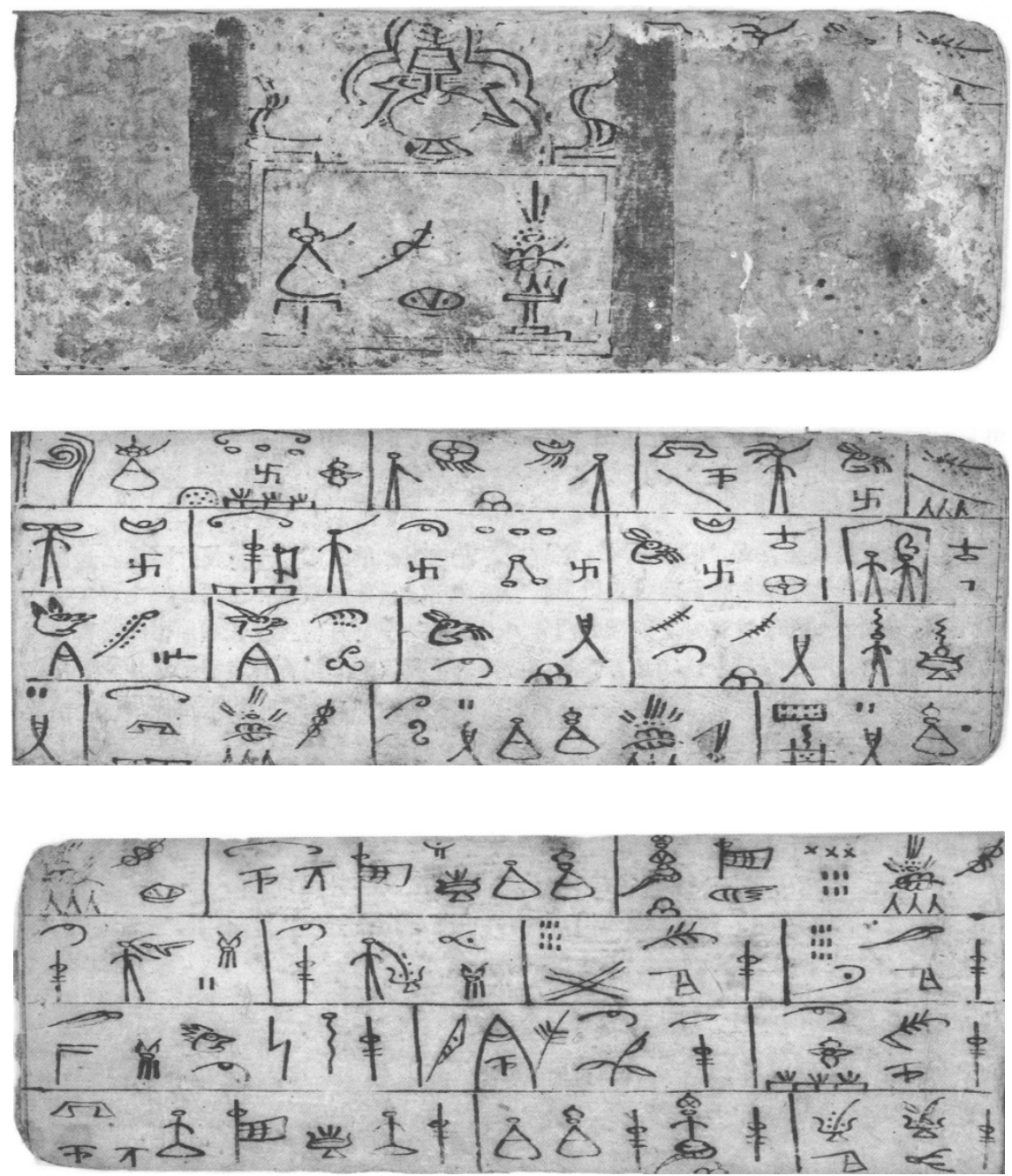

Figure 15. The domba documents used in the ritual "tsho ${ }^{55} \mathrm{pa}^{33} \mathrm{nctzi}^{55}$ " (The Institute of Domba Culture, 1999)

\section{Conclusion}

Dongba village suffers less influence from the Han culture, owing to its remote distance, so domba culture here is better preserved. During field investigation in Dongba village, we observe many traditional customs and religious rituals, which is nearly extinct in the developed Naxi districts.

Stick burning is an indispensable part in traditional Naxi's daily life. The Naxi people pray to the Naxi's Gods and ancestors for blessing, and burn sticks in the censer in or out of the house. If they pray for important things, they would hold formal praying rituals in the big censer. So censer is an indispensable appliance in the traditional Naxi families.

Through our field recording, we find that the censer building ritual is composed of four parts: divining the time and position, cleaning the building position, building the censer and holding the ritual of "tsho $\mathrm{O}^{55} \mathrm{pa}^{33}$ ndzi ${ }^{55}$ ". Except building the censer, the other three parts must be done or acted with the guidance of Domba. Domba is an indispensable and religious person in this religious work.

In traditional Naxi community, no matter what ritual is carried out, the ritual of stick burning is the necessary part. So building the big censer is an important thing in Naxi's life. But when it comes to modern times, the culture of stick burning is getting more and more simplified and seems to disappear in the developed Naxi areas, like Lijiang, especially because younger generations lack the knowledge of traditional Naxi culture. It is the microcosm of Naxi traditional culture. It is imperative to inherit and carry forward Naxi's traditional culture. Though we cannot prevent the traditional custom from disappearing, we can record them through field investigation. 
Naxi ethnic minority enjoys a charming culture with long history, and is famous for its special Domba culture. Domba culture contains Domba documents, Domba rituals, Domba dance, Domba music, Domba pictures and so on. And among them, the most important and the core are the Domba religious documents and rituals.

Domba religious documents and rituals are closely related. Domba religious documents are an essential tool in religious rituals, without which the religious ritual cannot be orderly carried out. Meanwhile Domba documents can survive and be inherited only when it is frequently used in religious rituals. Both of them are important and the core of the Domba culture.

Culture is an identity and belonging of an ethnic minority. Any identity without modifying is primordial. Those subjective feelings established in shared lineage, believing in common blood ancestry and interpretation of the shared culture, is of great importance to the group or ethic community (Fan, 2008). Culture identity is a sense of belonging of individual towards culture and cultured group...The most obvious characteristic is the ethic's distinctive culture (Yang, 2010).

\section{References}

Fan, K. (2008). Cultural Identity and Cultural Self-consciousness Under the Global Perspective. World Ethic, 2, $1-8$.

Li, M. L., \& Xu, J. C. (2007). The Tibetan Households'Custom of Weisang in Yunnan Province: With TwoTibetan Communities in Diqing Tibetan Autonomous Prefecture as the Cases. Ethno-National Studies, 5, 46-55.

Renmin Traffic Press. (2013). The highway mileage map of Southwest district: Yunnan province. Beijing.

The Institute of Domba Culture. (1999). An Annotated Collection of Naxi Dongba Manuscripts. Kunming: Yunnan Renming Press.

Wang, X. B. (2007). Writing, Ritual \& Cuktural Memory. Beijing: Ethnic Publishing Press.

Yang, F. Q. (2010). The ethic and religous culture identity influence bring out by social and cultural vicissitude. Sixiangzhanxian, 4, 15-20.

\section{Copyrights}

Copyright for this article is retained by the author(s), with first publication rights granted to the journal.

This is an open-access article distributed under the terms and conditions of the Creative Commons Attribution license (http://creativecommons.org/licenses/by/3.0/). 